\title{
Multi-objective optimization in single-row layout design using a genetic algorithm
}

\author{
N. Lenin ${ }^{1},{ }^{*}$ M. Siva Kumar ${ }^{2}$, M. N. Islam ${ }^{3}$ and D. Ravindran ${ }^{1}$ \\ ${ }^{1}$ Department of Mechanical Engineering, National Engineering College, K.R. Nagar, Kovilpatti, \\ Tamilnadu - 628 503, India. \\ ${ }^{2}$ Sree Sowdambika College of Engineering, Chettikurichi, Aruppukottai,Tamilnadu - 626 134, \\ India. \\ ${ }^{3}$ Department of Mechanical Engineering, Curtin University, GPO Box U 1987, Perth WA 6845, \\ Australia.
}

\begin{abstract}
This paper presents the development of a genetic algorithm for determining a common linear machine sequence for multi-products with different operation sequences and facilities with a limited number of duplicate machine types available for a job. This work aims to minimize the total flow distance travelled by products, reduce the number of machines arranged in the final linear sequence, and decrease the total investment cost of the machines used in the final sequence. We assume that product flow runs only in the forward direction, either via in-sequence or bypass movement. We demonstrate the effectiveness of the proposed algorithm by solving a typical layout design problem taken from literature, and several randomly generated problems. Results indicate that the proposed algorithm serves as a practical decision support tool for resolving layout problems in manufacturing facilities.
\end{abstract}

Keywords Facility layout · Linear sequencing · Genetic algorithm . Flow distance $\cdot$ Machine investment

\section{Introduction}

Modern product lifecycles have become shorter in recent years given rapid technological development. Manufacturing companies have responded to this problem by enhancing their production processes, giving rise to the concept of multi-product flow lines in manufacturing systems. The application of this concept to multiple product manufacturing has become a challenge among researchers and enterprises. Multi-product flow lines enable the simultaneous production of different commodities in a single flow line setup, thereby maximizing the manufacturing process [1]. Machine layout or flow line design involves determining the relative positions of machines (i.e., the layout) in facilities where a given product is manufactured.

Assembly cell layouts can be classified as a (a) unidirectional network loop layout, (b) linear single-row layout, (c) linear double-row layout, (d) circular layout, and (e) cluster layout [2,3]. A linear machine sequence is the most commonly used in production systems because of its simplicity and efficient flow structure [4,5], and because it lends itself to the arrangement of machines in a variety of flow configurations, such as a straight line, U-shaped line, serpentine line, or loop for a conveyor or automated guided vehicle system [6]. It presents the advantages of shorter flow distance, easier control of the production process, and easier material handling. It is also the most prevalent layout form in cellular

${ }^{*}$ Corresponding author email id: lawan_sisa@yahoo.com 
manufacturing systems and flexible manufacturing systems (FMSs) [7,5]. In this work, therefore, we choose a linear machine sequencing method.

\section{Literature review}

Many researchers have discussed the linear sequencing of machines for solving flow layout problems. Houshyar and McGinnis [8] introduced a heuristic for assigning facilities to locations for the purpose of minimizing the travel distance traversed during work progress in a straight track. The established heuristic exhibited better performance than did the modified and classical lower bound methods.

The triangle assignment algorithm was used by Heragu and Kusiak [4] in solving the machine layout problems in an FMS. The computational time of the proposed algorithm was comparable to that of existing methods. The authors [9] also presented two efficient models, namely, a linear continuous and linear mixed integer, for facility layout problems. The models do not necessitate prior knowledge of site locations. The authors showed that the continuous models are more useful for solving facility layout problems than are other models presented in literature.

Heragu and Alfa [3] experimentally analyzed simulated annealing-based algorithms, namely, a modified penalty algorithm, the simulated annealing algorithm, and a hybrid simulated annealing algorithm for single-row layout problems in facilities of unequal areas and for multi-row layout problems in facilities of equal areas. The authors concluded that the hybrid algorithm produces better quality solutions than do the first two algorithms, although the former involves slightly longer computational time.

Kouvelis and Chiang [10] implemented a simulated annealing procedure to determine a flow line (or single-row layout) under the assumptions that the number of machines is fixed and backtrack movements are allowed. The authors aimed to determine a machine sequence with minimum total backtrack distance.

Ho et al. [11] proposed two flow analysis methods for a multi-flow line layout design to realize shorter flow distances: The first method features a traditional line structure for analysis, whereas the second implements a network structure. The authors also developed a heuristic pattern-matching method for single-row layout problems in FMSs, in which a linear machine sequence is initially constructed for the product that entails the largest number of operations.

Braglia [12] regarded the linear machine sequencing problem as a nonpolynomial hard combinatorial problem. The number of possible sequences grows exponentially because the use of duplicate machines is allowed. Moreover, the set of all feasible sequences is not merely a set of simple permutations of a fixed number of machines given that the sequences must satisfy the different operation sequences of all products. The author determined a linear machine sequence with minimum expected movement of the machine handling device located between machines in a machine cell. The expected movement is determined by the frequency of part displacements between machines.

Wang et al. [13] formulated a model for minimizing the total material handling distance on a shop floor in both inter- and intra-cell facility layouts for cellular manufacturing systems. The authors used an improved simulated annealing algorithm to solve this problem.

Using a simulated annealing algorithm, Ho and Moodie [14] investigated a machine layout problem with a linear single-row flow line for an automated 
manufacturing system. The authors also investigated the effect of flow line characteristics on machine layouts. They provided vital information on selecting appropriate flow line analysis methods and determining appropriate evaluation criteria for different layout problems.

Chen et al. [15] addressed the problem of determining a common linear machine sequence for multi-products that have different operation sequences and facilities with a limited number of duplicate machine types. The authors intended to minimize the total flow distance travelled by products on this linear flow line by using a modified simulated annealing algorithm.

Diponegoro and Sarker [16] presented a two-stage solution methodology that simplifies computation and generates better solutions for reducing travel distances in production processes that involve sets of identical machines. This problem is often formulated as a tertiary assignment problem because of its combinatorial nature.

According to Hicks [17], layouts produced by a genetic algorithm-based optimization method significantly minimize material movement for a given work schedule in both greenfield and brownfield scenarios. A model for designing an FMS in one or multiple rows with genetic algorithms was discussed by Ficko et al. [18], who established the most favorable number of rows and the sequence of devices in an individual row by using genetic algorithms.

Chrysostomos and Vlachos [1] used the linear programming model for minimal backward flow to determine the optimal linear machine sequence in a manufacturing cell. They applied a modified ACS algorithm to the conditions and parameters of the linear machine layout problem. To determine the optimal linear placement of facilities with varying dimensions on a straight line, Anjosa et al. [19] introduced a semi-definite programming approach for the one-dimensional space-allocation problem, also known as the single-row facility layout problem.

Pillai et al. [20] identified a linear sequence that minimizes the total distance travelled by multiple items with different operation sequences. The authors regarded each type of machine available as limited, and adopted a simulated annealing algorithm in determining the best solution. Solimanpur et al. [21] formulated the single-row machine layout problem as a non-linear 0-1 programming model, in which the distance between the machines is sequence dependent. They developed an ant colony algorithm to solve this problem.

To minimize the total cost of material handling and maximize the requirements of adjacent resources, Gengui et al. [2] developed a multiple objective genetic algorithm approach with a local search method. On the basis of previously developed formulations, solution methodologies, and software packages, Singh et al. [22] discussed the current and future trends of research on facility layout problems. The authors observed a trend toward multi-objective approaches by developing facility layout software using meta-heuristics, such as simulated annealing, genetic algorithm, and concurrent engineering for facility layouts.

Andre and Amaral [23] proposed a mixed 0-1 linear program for the onedimensional facility layout problem to minimize the weighted sum of distances, while Teo and Ponnambalam [24] proposed a hybrid ACO/PSO heuristic to solve single-row layout problems. For apparel manufacturing, Lin [25] proposed a hierarchical order-based genetic algorithm to minimize the moving distance among cutting pieces in a U-shaped single-row machine layout.

Ramazan et al. [26] and Jannat et al. [5] both considered the same two objectives in solving flow layout problems: minimizing material handling costs 
and maximizing closeness rating scores. Ramazan et al. proposed a simulated annealing algorithm to identify the non-dominated solution (Pareto optimal) set, while Jannat et al. developed a genetic algorithm for the multi-objective facility layout problem and determined the optimal facility location for a particular problem.

Satheesh Kumar et al. [27] employed an artificial immune system algorithm to minimize material handling costs both in single-row and loop layout problems in FMSs. Siva Kumar M et al. [28] developed a simple heuristic to determine the optimal linear sequence that minimizes the flow distance travelled by products.

Despite the considerable effort directed toward solving flow layout problems, most of these studies focused on the optimization of a single parameter only-flow distance. In practice, however, the total number of machines in a layout and the total investment cost of machines are equally important factors. In this work, we aim to determine the linear sequence of machine arrangement that minimizes total flow distance in units; total number of machines in the final linear sequence; and total investment cost of machines.

\section{Problem definition}

The locations and number of machines in a linear machine sequence of a singlerow layout design are keys to determine the flow distance of multi-products and total investment cost of machines. In facilities with duplicate machines and multiple products, the single-row layout design is considered a non-polynomial hard problem [12].

We present the following assumptions in the proposed method:

a) The number of products, demand for products, machine type sequences, and individual costs of machines are known, along with the availability of duplicate machines.

b) The products always enter the first machine to which they are assigned in the final linear machine sequence.

c) The products' flow distances extend to the end of the respective machine types of the products without affecting the preceding flow.

d) The machines have sufficiently large capacities.

e) Backtracking is prohibited.

\section{Mathematical model}

The total flow distance of a product in units $(t d)$ is determined using Eq. 1. The constraints are presented in Eqs. 2-6:

$$
t d=\sum_{i=1}^{n p} \sum_{j=1}^{n m_{i}} d_{i}\left(L_{i j+1}-L_{i j}\right)
$$

where

$t d \quad-$ total flow distance;

$d_{i} \quad-\mathrm{i}^{\text {th }}$ product flow distance;

$L_{i j+1} \quad-i^{\text {th }}$ product's $j+1^{\text {th }}$ machine location in the final machine

sequence;

$L_{i j} \quad-i^{\text {th }}$ product's $j^{\text {th }}$ machine location in the final machine sequence 
$n p \quad-$ number of products;

$n m_{i} \quad-$ number of machines in the $\mathrm{i}^{\text {th }}$ product machine sequence.

$$
\begin{aligned}
& L_{i j+1}>L_{i j} \\
& L_{i j}>L_{i 1} \\
& n m_{k} \leq n d m_{k}
\end{aligned}
$$

where

$n m_{k} \quad-$ number of $\mathrm{k}^{\text {th }}$ machines available in the final linear machine sequence;

$n d m_{k}-$ number of duplicate $\mathrm{k}^{\text {th }}$ machine types available for use.

$$
t m=\sum_{k=1}^{n m t} n d m_{k}
$$

where

tm - total number of machines available for use;

nmt - number of machine types;

$k \quad-$ index that represents machine type $k=1,2,3, \ldots . n m t$.

where

$$
n m s \leq t m
$$

nms - total number of machines available in the final linear sequence.

Equation 2 shows that the location of the $j+1^{\text {th }}$ machine should always be larger than the location of the $j^{\text {th }}$ machine in the linear machine sequence. Equation 3 indicates that the location of the $j+1^{\text {th }}$ machine in the individual product machine sequence should always be larger than the location of the first machine in the linear machine sequence. According to Eq. 4, the number of $k^{\text {th }}$ machines types available in the final linear machine sequence should be less than or equal to the number of duplicate $k^{\text {th }}$ machine types available for use. The total number of machines is equal to the sum of the duplicates of individual machine types; this total is given in Eq. 5. Equation 6 shows that the total number of machines in the linear sequence must be less than or equal to the total number of machines available for use, including the duplicate machines.

\subsection{Total number of machines in the final linear sequence}

The minimum number of machines in the final linear sequence (nms) of the single-row layout design reduces both flow distance and initial investment. This reduction can be expressed using

$$
n m s=\operatorname{count}(b[\ldots . . .]),
$$

where $b[\ldots . .$.$] represents the final linear machine sequence.$ 


\subsection{Investment cost of machines}

Companies prefer to reduce not only their operation/manufacturing costs but also their initial investment. In the single-row layout design, the investment cost of machines is expressed by

$$
t c=\sum_{k=1}^{n m t} c_{k} n m_{k}
$$

where

tc - total investment cost of machines in the final linear sequence;

$c_{k} \quad-$ cost of the $\mathrm{k}^{\text {th }}$ machine type.

\subsection{Average fitness factor}

The total flow distance in units, total number of machines in the final linear sequence, and total investment cost of machines are at different ranges or levels. Summing up the above-mentioned values of different levels will not produce the best result. We therefore apply the average fitness factor method [29] to derive values within the range of 0 to 1 . The normalized values of total flow distance, total number of machines, and investment cost of machines are determined using Eqs. 9-11.

$$
\begin{aligned}
n t d_{l} & =\frac{t d_{\max }-t d_{l}}{t d_{\max }-t d_{\min }} \\
n n m s_{l} & =\frac{n m s_{\max }-n m s_{l}}{n m s_{\max }-n m s_{\min }} \\
n t c_{l} & =\frac{t c_{\max }-t c_{l}}{t c_{\max }-t c_{\min }}
\end{aligned}
$$

\begin{tabular}{|c|c|}
\hline$n t d_{l}$ & $\begin{array}{l}\text { - normalized value of the total flow distance of multi- } \\
\text { products for the } l^{\text {th }} \text { sequence of products; }\end{array}$ \\
\hline$n_{n m s}$ & $\begin{array}{l}\text { - normalized value of the total number of machines in the } \\
\text { final linear machine sequence for the } l^{\text {th }} \text { sequence of } \\
\text { products; }\end{array}$ \\
\hline$n t c_{l}$ & $\begin{array}{l}\text { - normalized value of the total investment cost of } \\
\text { machines for the } l^{\text {th }} \text { sequence of products; }\end{array}$ \\
\hline$t d_{\min }$ and $t d_{\max }$ & $\begin{array}{l}\text { - minimum and maximum values of the total flow distance } \\
\text { for } 1,2,3, \ldots l \text { number of sequences of products; }\end{array}$ \\
\hline$n m s_{\min }$ and & - minimum and maximum number of machines in the \\
\hline & $\mathrm{s}$ \\
\hline$t c_{\min }$ and $t c_{\max }$ & $\begin{array}{l}\text { - minimum and maximum values of the total investment } \\
\text { cost of machines for } 1,2,3, \ldots l \text { number of sequences } \\
\text { of products; }\end{array}$ \\
\hline$t d_{l}$ & $\begin{array}{l}\text { - total flow distance of multi-products for the } l^{\text {th }} \\
\text { sequence of products; }\end{array}$ \\
\hline$n \mathrm{~ns}_{l}$ & $\begin{array}{l}\text { - total number of machines in the final sequence of the } l^{\text {th }} \\
\text { sequence of products; }\end{array}$ \\
\hline
\end{tabular}

where 
The average fitness factor value is determined by Eq. 12. In the minimization problem, the maximum value of the average fitness factor is considered.

$$
n d m c_{l}=\frac{n t d_{l}+n n m s_{l}+n t c_{l}}{3}
$$

where

$n d m c_{l} \quad-$ average fitness factor for the $l^{\text {th }}$ sequence of products.

The corresponding linear machine sequence of the aforementioned maximum average fitness factor value is the optimum sequence among the $l$ number of sequences of products.

\section{Genetic algorithm}

The basic concept of genetic algorithms is explained in Gengui et al. [2]. In the present work, the product numbers are considered as genes, the product sequences are regarded as chromosomes, and the number of products is viewed as chromosome length. The general schematic of the genetic algorithm proposed in the current paper is shown in Fig. 1.

The proposed algorithm yields consistent solutions with minimum total flow distance, minimum number of machines, and minimum total investment cost of machines with acceptable computational time. A detailed numerical illustration is provided in the succeeding section.

\section{Numerical illustration}

The following example problem is considered to illustrate the effectiveness of the proposed genetic algorithm. Table 1 shows the number of machine types (M.No.), their availability, and their individual costs.

The product number (P.No.), individual product's machine type sequences, and demand for the product in units (flow distance) are listed in Table 2.

The product numbers (e.g., 1, 2, 3, 4, 5, 6) are genes, whereas the product sequences (e.g., 1-3-4-5-2-6) are chromosomes. The chromosome length is the number of products involved in the problem. The roulette wheel selection is used for the selection of reproduction. The single-point cross-over technique is adopted for the search of new strings in the search space. After many trials, the cross-over and mutation probabilities considered are 0.5 and 0.02 , respectively [30]. The complete replacement policy is implemented because it yields better results [30].

The $\mathrm{C}$ program developed for this purpose terminates automatically when no further change occurs in the previously derived best solutions, and it operates for an additional 50 iterations to ascertain the best solution obtained in continuous mode. The number of iterations required (e.g., 1,000) may be incorporated into the developed program. Table 3 shows the initial population and Fig. 2 presents the flow chart of chromosome evaluation. The detailed procedure for calculating the final machine sequence for product sequence 1-3-4-5-2-6 is presented in Table 4. The flow distance and total investment cost of machines for the aforementioned product sequence are listed in Tables 5 and 6, respectively. The final machine 
sequence, total investment cost of machines, total number of machines, and total flow distance of the individual chromosomes are presented in Table 7.

The calculated values of total flow distance in units, total number of machines in the final linear sequence, and total investment cost of machines are at different levels. To obtain the same level for all three, we introduce an average fitness factor method (Table 8) [25]. The fitness function is considered the sum of all the normalized values of $\mathrm{Z1}, \mathrm{Z2}$, and $\mathrm{Z3}$, and the new fitness values are calculated on the basis of the expression given below. Equation 14 is used to determine the probability of the chromosomes. The probability and cumulative probability of the individual chromosomes are listed in Table 8.

$$
\begin{gathered}
n f\left(x_{i}\right)=\mathrm{E}^{-0.55 f\left(x_{i}\right)} \\
\operatorname{pro}_{i}=\frac{n f\left(x_{i}\right)}{\sum_{i=1}^{c n o} n f\left(x_{i}\right)}
\end{gathered}
$$

where

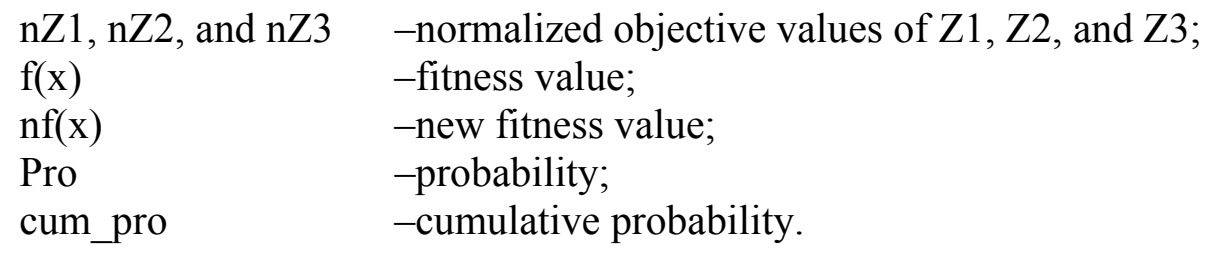

We generate a random number $\left(r_{s r p}\right)$ for each chromosome to select the reproduction process. From Table 8, we choose the chromosomes that correspond to the cumulative probability value, which is the next highest value after $r_{s r p}$. Table 9 lists the chromosomes selected for reproduction. The cross-over probability ( $p_{-} c r o$ ) is assumed to be 0.6 , and a random number $\left(r_{c o}\right)$ is generated for each chromosome selected for reproduction. The chromosome is chosen for cross-over operation only if $r_{c o}$ is less than or equal to $p_{-}$cro.

A random number $\left(r_{c p}\right)$ is generated within the number of products $(n p)$ for each chromosome selected for cross-over. The genes after and before the cutting point $\left(r_{c p}\right)$ are interchanged and presented in Table 10.

To avoid local minima, mutation is carried out using the genetic algorithm. A value of 0.02 is assumed as the mutation probability ( $p_{-}$mut), and a random number $\left(r_{m}\right)$ is generated for each gene of all the chromosomes. If $r_{m}$ is less than or equal to $p \_m u t$, then the corresponding gene is mutated with a neighbor gene (Table 11).

A complete replacement strategy is assumed, which replaces the initial population with the mutated chromosomes. Table 12 shows the chromosomes generated after the first iteration. The above-mentioned steps are repeated until a specific number of iterations is reached.

\section{Computational results and discussion}

We use the proposed algorithm to solve additional problems; the ones discussed in this paper are the first five problems solved by Pillai et al. [20], Chen et al. [15], and Siva Kumar M et al. [28], as well as problems that are randomly generated. Input data, such as the number of products and their machine type sequences and 
product demand, are listed in Appendix Table A1. The number of machine types and their duplicate numbers are listed in Appendix Table A2. The cost of individual machine types is listed in Appendix Table A3. The final linear machine sequence, product sequence, total flow distance, total machine cost, and total number of machines in the final linear sequence are presented in Table 13.

${ }^{\#}$ In Figs. 7-9, the $\mathrm{Y}$ axis value is the sum of flow distance (considered in 1,000), investment cost of machines (considered in 100,000) and number of machines in the final machine sequence.

The computational results of the proposed method (i.e., total flow distance, total investment cost of machines, and total number of machines in the final linear sequence) are compared with the findings of Siva Kumar $\mathrm{M}$ et al. [28] and Chen et al. [15]. The comparisons of the individual objective functions are illustrated in Figs. 3-5, which show that the proposed method is superior to the other two methods. In all the problems, the proposed method generates lower objective values. In the first two problems, the three methods derive equal objective values. In problem numbers 7 and 8, the method proposed by Siva Kumar M et al. [28] produces an infeasible solution. The comparison of the combined objectives of the above-mentioned methods is illustrated in Fig. 6, which shows that the proposed method produces a minimum objective value. Figures 7-9 demonstrate that the proposed method not only produces lower values of individual objective functions, but also yields minimum combined objective values compared with the other approaches. From these illustrations, we conclude that the proposed algorithm yields the best linear sequence of machines; it minimizes the total flow distance in units, total investment cost of machines, and total number of machines.

The proposed algorithm yields minimum flow distance, minimum number of machines, and minimum investment cost of machines because of the following reasons:

a) Machines are assigned not on the basis of the descending order of the flow distance of a product's sequence.

b) The number of machines used in every machine type in the final linear machine sequence is reduced.

c) The unassigned machine types are incorporated at the front or back flow of the existing machine sequence, depending on availability.

d) If one of the machine types is assigned and it is available in the existing sequence, its availability in this sequence is verified even if the remaining machine types are unassigned. If any of the remaining machine types are unavailable in the existing sequence and are unassigned, then the machine type is incorporated at the back flow of the existing sequence without affecting the previous product machine type sequences.

\section{Conclusion}

The linear sequence of machines in a layout design determines the flow distance and investment cost of machines for multi-products of different operation sequences with a single or limited number of duplicate machines of each type. We proposed a genetic algorithm for constructing a linear sequence of machines that minimizes total flow distance in units, total investment cost of machines, and total number of machine types arranged in the final linear sequence. We conclude that the proposed method is highly efficient both in individual objective functions and in combined objective functions. Other than the problems discussed in literature, several other problems were generated and experimented on using the proposed algorithm. Compared with previous approaches, our method generates more 
favorable results. As an extension to this work, we will consider the material handling costs of machine types. Optimization techniques such as PSO and Tabu Search may also be used to solve problems.

\section{References}

1. Chrysostomos F and Vlachos A (2005). Optimal solution of linear machine layout problem using ant colony system. Proceedings of the 9th WSEAS International Conference on Computers, Athens, Greece: World Scientific and Engineering Academy and Society (WSEAS), 97.

2. Gengui Zhou, Mujing Ye, Zhenyu Cao and Feng Ye (2006). A genetic algorithm approach on a facility layout design problem with aisles. Lecture notes in computer science, Computational Intelligence. 4114/2006: 10081013.

3. Heragu SS and Alfa AS (1992). Experimental analysis of simulated annealing based algorithms for the layout problem. European Journal of Operational Research. 57: 190-202.

4. Heragu SS and Kusiak A (1988). Machine layout problem in flexible manufacturing systems. Operations Research. 36: 258-268.

5. Jannat S, Khaled AA and Sanjoy Kumar Paul (2010). Optimal solution for multi-objective facility layout problem using genetic algorithm. Proceedings of the 2010 International Conference on Industrial Engineering and Operations Management, Dhaka, Bangladesh.

6. Aneke NA and Carrie AS (1986). A design technique for layout of multiproduct flowlines. International Journal of Production Research. 24: 471- 481.

7. Ho YC, Lee CEC and Moodie CL (1993). Two sequence-pattern, matchingbased, flow analysis methods for multi-flowlines layout design. International Journal of Production Research. 31: 1557-1578.

8. Houshyar A and McGinnis LF (1990). A heuristic for assigning facilities to locations to minimize WIP travel distance in a linear facility. International Journal of Production Research. 28: 1485 - 1498.

9. Heragu SS and Kusiak A (1989). Machine layout: An optimization and knowledge-based approach. International Journal of Production Research. 28: 615- 635 .

10. Kouvelis P and Chiang WC (1992). A simulated annealing procedure for single row layout problems in flexible manufacturing systems. International Journal of Production Research. 30: 717-732.

11. Ho YC, Lee CEC and Moodie CL (1993). Two sequence-pattern, matchingbased, flow analysis methods for multi-flowlines layout design. International Journal of Production Research. 31: 1557-1578.

12. Braglia M (1997). Heuristics for single-row layout problems in flexible manufacturing problems. Production Planning and Control. 8: 558-567.

13. Wang TY, Lin HC and Wu KB (1998). An improved simulated annealing for facility layout problems in cellular manufacturing systems. Computers \& Industrial Engineering. 34(2): 309-319.

14. Ho YC and Moodie CL (1998). Machine layout with a linear single-row flow path in an automated manufacturing system. Journal of Manufacturing Systems. 17(1): 1-22.

15. Chen DS, Wang Q and Chen HC (2001). Linear sequencing for machine layouts by a modified simulated annealing. International Journal of Production Research. 39(8): 1721 - 1732. 
16. Diponegoro A and Sarker BR (2003). Flow distance reduction for a multiproduct flowline with sets of identical machines. European Journal of Operational Research. 147: 591-612.

17. Hicks C (2004). A genetic algorithm tool for designing manufacturing facilities in the capital goods industry. International Journal of Production Economics. 90(2): 199-211.

18. Ficko M, Brezocnik M and Balic J (2004). Designing the layout of single- and multiple-rows flexible manufacturing system by genetic algorithms. Journal of Materials Processing Technology. 157-158: 150-158.

19. Anjosa MF, Kenningsb A and Vannellib A (2005). A semidefinite optimization approach for the single-row layout problem with unequal dimensions. Discrete Optimization. 2: 113-122.

20. Pillai. VM and Gudivada BS (2005). A simulated annealing algorithm for linear sequencing of machines for layout design. Sixth Int. Conference on Operations and Quantitative Management, Indore, India.

21. Solimanpur M, Prem Vrat and Ravi Shankar (2005). An ant algorithm for the single row layout problem in flexible manufacturing systems. Computers \& Operations Research. 32(3): 583-598.

22. Singh SP and Sharma RRK (2006). A review of different approaches to the facility layout problems. In. J. Adv. Manuf. Techn. 30 (5-6): 425-433.

23. André RS and Amaral (2008). An exact approach to the one-dimensional facility layout problem. Operations Research. 56: 1026-1033.

24. Teo YT and Ponnambalam SG (2008). A hybrid ACO/PSO heuristic to solve single row layout problem. CASE 2008. IEEE International Conference on Automation Science and Engineering. Washington, DC, USA. $597-602$.

25. Lin MT (2009). The single-row machine layout problem in apparel manufacturing by hierarchical order-based genetic algorithm. International Journal of Clothing Science and Technology. 21(1): 31-43.

26. Ramazan Ş and Orhan T (2009). A simulated annealing algorithm to find approximate pareto optimal solutions for the multi-objective facility layout problem. In. J. Adv. Manuf. Techn. 41 (9-10): 1003-1018.

27. Satheesh Kumar M, Asokan P and Kumanan S (2010). An artificial immune system-based algorithm to solve linear and loop layout problems in flexible manufacturing systems. International Journal of Product Development. 10(13): $165-179$.

28. Siva Kumar M, Islam MN, Lenin N, Vignesh Kumar D and Ravindran D (2011). A simple heuristic for linear sequencing of machines in layout design. International Journal of Production Research. 49 (22): 6749-6768.

29. Sivakumar K, Balamurugan C and Ramabalan S (2011). Simultaneous optimal selection of design and manufacturing tolerance with alternative manufacturing process selection. Computer-Aided Design. 43: 207-218.

30. Siva Kumar M and Kannan SM (2007). Optimum manufacturing tolerance to selective assembly technique for different assembly specifications by using genetic algorithm. In. J. Adv. Manuf. Techn. 32 (5-6): 591-598. 
Table 1. Details of machine, its availability and cost.

\begin{tabular}{cccccccccc}
\hline M.No. & 1 & 2 & 3 & 4 & 5 & 6 & 7 & 8 & 9 \\
\hline $\begin{array}{c}\text { Availability } \\
\text { of duplicate machines }\end{array}$ & 2 & 1 & 2 & 2 & 1 & 1 & 2 & 2 & 2 \\
$\begin{array}{c}\text { Machine cost } \\
\text { (Rs.) }\end{array}$ & 24121 & 4546 & 25742 & 27159 & 26738 & 18822 & 21612 & 979 & 12257 \\
\hline
\end{tabular}

Table 2. Details of machine sequence and demand of individual product.

\begin{tabular}{ccc}
\hline P.No. & Machine sequence & Demand in units \\
\hline 1 & $4-6-8-1$ & 8 \\
2 & $7-1-8-2$ & 15 \\
3 & $5-6-9-8-3$ & 32 \\
4 & $3-5-1-8$ & 50 \\
5 & $5-9-8-1-7$ & 42 \\
6 & $4-6-2-9$ & 29 \\
\hline
\end{tabular}

Table 3. Initial population

\begin{tabular}{cc}
\hline C.No. - Chromosome number & Chromosomes \\
\hline 1 & $1-3-4-5-2-6$ \\
2 & $2-3-1-5-6-4$ \\
3 & $2-3-5-4-6-1$ \\
4 & $2-6-3-4-5-1$ \\
5 & $3-4-1-5-6-2$ \\
6 & $6-1-2-3-4-5$ \\
7 & $2-3-1-6-5-4$ \\
\hline
\end{tabular}


Table 4. Final machine sequence for the product sequence 1-3-4-5-2-6.

\begin{tabular}{|c|c|c|c|c|c|c|c|c|c|c|c|c|c|c|c|c|c|c|c|c|c|c|c|c|c|c|c|c|c|c|c|}
\hline \multirow{3}{*}{$\begin{array}{l}\mathrm{P} \\
\text { No. }\end{array}$} & \multirow{3}{*}{\multicolumn{5}{|c|}{$\begin{array}{l}\text { Product's } \\
\text { machines } \\
\text { sequence }\end{array}$}} & \multicolumn{16}{|c|}{ Machine types } & 1 & 2 & 3 & 4 & 5 & 6 & 7 & 8 & 9 & Machine type numbers \\
\hline & & & & & & \multicolumn{16}{|c|}{ Nos. of duplicate machine types available } & 2 & 1 & 2 & 2 & 1 & 1 & 2 & 2 & 2 & Available machines type in stock \\
\hline & & & & & & \multicolumn{9}{|c|}{$\begin{array}{c}\text { Machines available in stock after } \\
\text { assignment }\end{array}$} & \multicolumn{16}{|c|}{ Existing machine sequence } & Remarks \\
\hline 1 & 4 & 6 & 8 & 1 & & 1 & 1 & 2 & 1 & 1 & 0 & 2 & 1 & 2 & 4 & 6 & 8 & 1 & & & & & & & & & & & & & $\begin{array}{l}\text { All machine types are available in stock } \\
\text { ie. Mtn[mno] }<>0\end{array}$ \\
\hline \multirow[t]{2}{*}{3} & 5 & 6 & 9 & 8 & 3 & 1 & 1 & 2 & 1 & 0 & 0 & 2 & 1 & 2 & 5 & 4 & 6 & 8 & & $L$ & & & & & & & & & & & $\begin{array}{l}\text { Machine } 5 \text { is available in stock. Add this } \\
\text { machine in front of the existing sequence. } \\
\text { Machine } 6 \text { is unavailable in stock. Hence, } \\
\text { search the machine } 6 \text { in existing } \\
\text { sequence. It is available in the existing } \\
\text { sequence and take the next machine } 9 \text {. }\end{array}$ \\
\hline & & & 9 & 8 & 3 & 1 & 1 & 1 & 1 & 0 & 0 & 2 & 0 & 1 & 5 & 4 & 6 & 8 & & 1 & 9 & 8 & 3 & & & & & & & & $\begin{array}{l}\text { Machine } 9 \text { is unavailable in existing } \\
\text { sequence after machine } 6 \text { but available in } \\
\text { stock. Hence, add it at the end of existing } \\
\text { sequence. Similarly, add machine } 8 \text { and } 3 \\
\text { at the end of existing sequence since, it is } \\
\text { available in stock. }\end{array}$ \\
\hline 4 & 3 & 5 & 1 & 8 & & 1 & 1 & 0 & 1 & 0 & 0 & 2 & 0 & 1 & 3 & 5 & 4 & 6 & & 3 & 1 & 9 & 8 & 3 & & & & & & & $\begin{array}{l}\text { Machine } 3 \text { is available in stock. But } \\
\text { machine } 5 \text { is unavailable in stock and } \\
\text { available in existing sequence. Similarly, } \\
\text { machine } 1 \text { and } 8 \text { are also available in the } \\
\text { existing sequence after machine } 5 .\end{array}$ \\
\hline 5 & 5 & 9 & 8 & 1 & 7 & 1 & 1 & 0 & 1 & 0 & 0 & 2 & 0 & 1 & 3 & 5 & 4 & 6 & & 3 & 1 & 9 & 8 & 3 & & & & & & & $\begin{array}{l}\text { Machine } 5 \text { is unavailable in stock. But } \\
\text { available in the existing sequence. } \\
\text { Similarly, machine } 9 \text { and } 8 \text { are also } \\
\text { available in the existing sequence after } \\
\text { machine } 5 \text {. }\end{array}$ \\
\hline
\end{tabular}




\begin{tabular}{|c|c|c|c|c|c|c|c|c|c|c|c|c|c|c|c|c|c|c|c|c|c|c|c|c|c|c|c|c|}
\hline & & & & 17 & 0 & 1 & 0 & 1 & 0 & 0 & 1 & 0 & 1 & 3 & 5 & 4 & 6 & 8 & 1 & 9 & 8 & 3 & 1 & 7 & & & & $\begin{array}{l}\text { Machine } 1 \text { is not available in the existing } \\
\text { sequence after machines } 9 \text { and } 8 \text {. But } \\
\text { machines } 1 \text { and } 7 \text { are available in stock. } \\
\text { Add these machines at the end of existing } \\
\text { sequence. }\end{array}$ \\
\hline \multirow[t]{2}{*}{2} & 7 & 1 & 8 & 2 & 0 & 1 & 0 & 1 & 0 & 0 & 0 & 0 & 1 & 7 & 3 & 5 & 4 & 6 & 8 & 1 & 9 & 8 & 3 & 1 & 7 & & & $\begin{array}{l}\text { Machine } 7 \text { is available in stock. Add the } \\
\text { machine } 7 \text { in front of the existing } \\
\text { sequence. }\end{array}$ \\
\hline & & 1 & 8 & 2 & 0 & 0 & 0 & 1 & 0 & 0 & 0 & 0 & 1 & 7 & 3 & 5 & 4 & 6 & 8 & 1 & 9 & 8 & 3 & 1 & 7 & 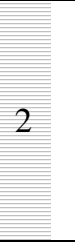 & & $\begin{array}{l}\text { Machines } 1 \text { and } 8 \text { are unavailable in } \\
\text { stock. But available in the existing } \\
\text { sequence. Machine } 2 \text { unavailable in } \\
\text { existing sequence after machines } 1 \text { and } 8 \text {, } \\
\text { but available in stock, Hence add at the } \\
\text { end of existing sequence. }\end{array}$ \\
\hline \multirow[t]{2}{*}{6} & 4 & 6 & 2 & 9 & 0 & 0 & 0 & 0 & 0 & 0 & 0 & 0 & 1 & 4 & 7 & 3 & 5 & 4 & 6 & 8 & 1 & 9 & 8 & 3 & 1 & 7 & 2 & $\begin{array}{c}\text { Machine } 4 \text { is available in stock. Add the } \\
\text { machine } 4 \text { in front of the existing } \\
\text { sequence. }\end{array}$ \\
\hline & & 6 & 2 & 9 & 0 & 0 & 0 & 0 & 0 & 0 & 0 & 0 & 0 & 4 & 7 & 3 & 5 & 4 & 6 & 8 & 1 & 9 & 8 & 3 & 1 & 7 & 2 & $\begin{array}{c}\text { Machines } 6 \text { and } 2 \text { are unavailable in } \\
\text { stock. But available in the existing } \\
\text { sequence. Machine } 9 \text { is unavailable after } \\
\text { machines } 6 \text { and } 2 \text { in the existing sequence } \\
\text { but available in stock, hence add machine } \\
9 \text { at the end of existing sequence. }\end{array}$ \\
\hline
\end{tabular}

\begin{tabular}{|l|l|l|}
\hline & Product number & $\begin{array}{l}\text { Machines available in stock after } \\
\text { assignment }\end{array}$ \\
\hline $\begin{array}{l}\text { Assigned machine before the existing machine } \\
\text { sequence }\end{array}$ & $\begin{array}{l}\text { Machine type already available in the } \\
\text { existing sequence }\end{array}$ \\
\hline & Assigned machine after the existing machine sequence & \multicolumn{2}{|l}{} \\
\hline
\end{tabular}


Table 5. Determination of flow distance for the final machine sequence of product sequence 1-3-4-5-2-6.

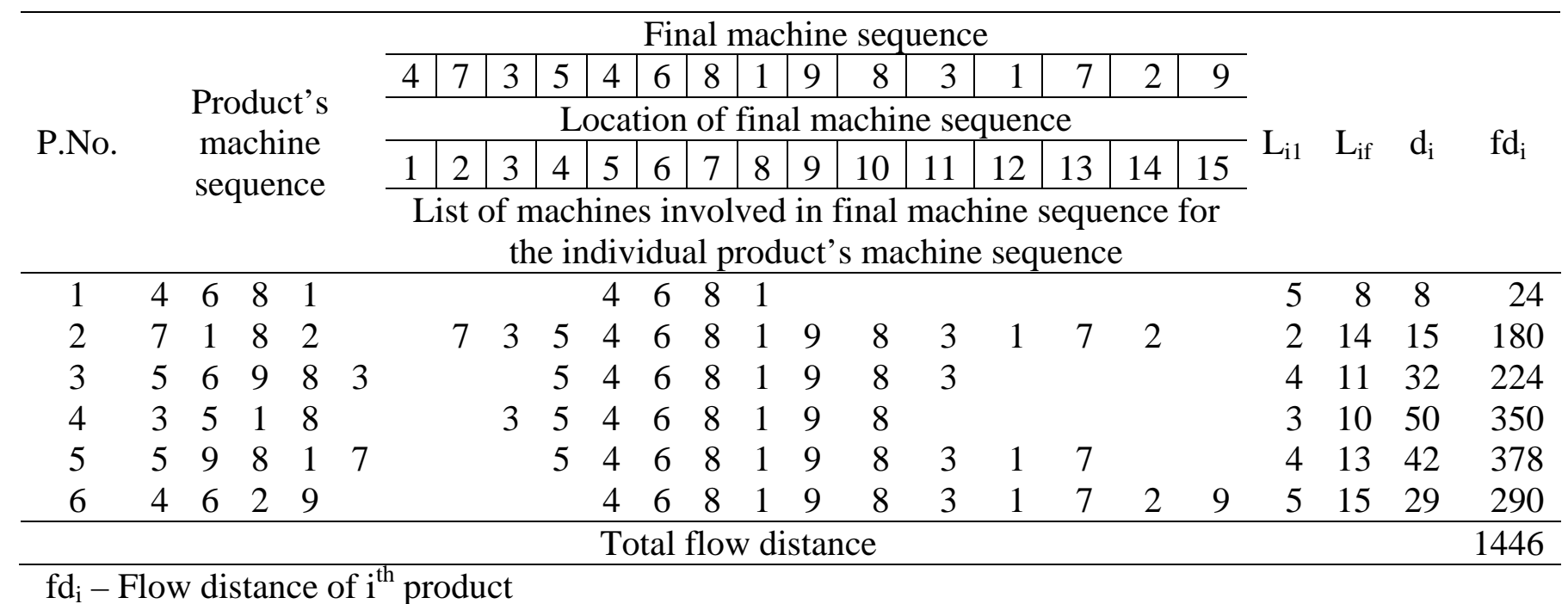

Table 6. Determination of total investment cost of machines for the final machine sequence of product sequence 1-3-4-5-2-6.

\begin{tabular}{|c|c|c|c|c|c|c|c|c|c|c|}
\hline Machine type & 1 & 2 & 3 & 4 & 5 & 6 & 7 & 8 & 9 & Total \\
\hline No. of machine type available in final sequence & 2 & 1 & 2 & 2 & 1 & 1 & 2 & 2 & 2 & investment \\
\hline Cost of machine type in Rs. & 24121 & 4546 & 25742 & 27159 & 26738 & 18822 & 21612 & 979 & 12257 & $\begin{array}{l}\text { machines } \\
\text { in Rs. }\end{array}$ \\
\hline Investment cost of each machine types in Rs. & 48242 & 4546 & 51484 & 54318 & 26738 & 18822 & 43224 & 1958 & 24514 & $2,73,846$ \\
\hline
\end{tabular}


Table 7. Evaluation result of chromosomes.

\begin{tabular}{ccccc}
\hline C.No. & Machine sequence & $\begin{array}{c}\text { Total } \\
\text { investment } \\
\text { cost of } \\
\text { machines } \\
(\mathrm{Z} 1)\end{array}$ & $\begin{array}{c}\text { Total number } \\
\text { of machines } \\
(\mathrm{Z2})\end{array}$ & $\begin{array}{c}\text { Total } \\
\text { flow } \\
\text { distance in } \\
\text { units (Z3) }\end{array}$ \\
\hline 1 & $4-7-3-5-4-6-8-1-9-8-3-1-7-2-9$ & 273846 & 15 & 1446 \\
2 & $3-4-5-6-9-8-3-7-1-8-2-7-9$ & 222566 & 13 & 1376 \\
3 & $4-3-5-6-9-8-3-7-1-8-2-7-9$ & 222566 & 13 & 1363 \\
4 & $4-3-5-4-6-7-1-8-2-9-8-3-1-7$ & 261589 & 14 & 1341 \\
5 & $7-1-4-3-5-6-9-8-3-1-8-7-2-9$ & 246687 & 14 & 1327 \\
6 & $3-5-7-1-8-4-6-2-9-8-1-3-7$ & 234430 & $\mathbf{1 3}$ & $\mathbf{1 1 8 4}$ \\
7 & $3-4-5-6-9-8-3-7-1-8-2-9-7$ & 22566 & 13 & 1389 \\
\hline \multicolumn{7}{c}{ Minimum } & 222566 & 13 & 1184 \\
\hline
\end{tabular}

Table 8. Probability and cumulative probability of the chromosomes.

\begin{tabular}{cccccccc}
\hline C.No. & $\mathrm{nZ1}$ & $\mathrm{nZ2}$ & $\mathrm{nZ3}$ & $\mathrm{f}(\mathrm{x})$ & $\mathrm{nf}(\mathrm{x})$ & Pro & cum_pro \\
\hline 1 & 0 & 0 & 0 & 0 & 1 & 0.18387 & 0.18387 \\
2 & 1 & 1 & 0.267176 & 2.267176 & 0.711716 & 0.130863 & 0.314733 \\
3 & 1 & 1 & 0.316794 & 2.316794 & 0.706439 & 0.129893 & 0.444625 \\
4 & 0.239021 & 0.5 & 0.400763 & 1.139784 & 0.842849 & 0.154974 & 0.599599 \\
5 & 0.529622 & 0.5 & 0.454198 & 1.48382 & 0.800457 & 0.14718 & 0.746779 \\
6 & 0.768643 & 1 & 1 & 2.768643 & 0.660145 & 0.121381 & 0.868159 \\
7 & 1 & 1 & 0.217557 & 2.217557 & 0.717033 & 0.131841 & 1 \\
\hline nZ1, nZ2 and nZ3 - normalized objective values of Z1, Z2 and Z3; f(x) - fitness \\
value; nf(x) - new fitness value; Pro - probability; cum_pro - cumulative \\
probability
\end{tabular}

Table 9. Selected chromosomes for reproduction.

\begin{tabular}{ccccc}
\hline C.No. & $\boldsymbol{r}_{\boldsymbol{s} \boldsymbol{r} \boldsymbol{p}}$ & O.C.No. & R.C.No. & $\begin{array}{c}\text { Selected Chromosomes } \\
\text { for reproduction }\end{array}$ \\
\hline 1 & 0.6300 & 5 & $1^{\prime}$ & $3-4-1-5-6-2$ \\
2 & 0.4100 & 3 & $2^{\prime}$ & $2-3-5-4-6-1$ \\
3 & 0.1250 & 1 & $3^{\prime}$ & $1-3-4-5-2-6$ \\
4 & 0.8300 & 6 & $4^{\prime}$ & $6-1-2-3-4-5$ \\
5 & 0.260 & 2 & $5^{\prime}$ & $2-3-1-5-6-4$ \\
6 & 0.7300 & 6 & $6^{\prime}$ & $6-1-2-3-4-5$ \\
7 & 0.3250 & 3 & $7^{\prime}$ & $2-3-5-4-6-1$ \\
\hline
\end{tabular}

$\boldsymbol{r}_{\text {srp }}$ - random number for selection for reproduction; O.C.No. - old chromosome number; R.C.No. - selected chromosomes for reproduction 
Table 10. Chromosomes before and after cross over.

\begin{tabular}{|c|c|c|c|c|c|c|}
\hline \multirow[b]{2}{*}{ R.C.No. } & \multicolumn{2}{|l|}{ Chromosomes } & \multirow[b]{2}{*}{ Selected } & \multicolumn{3}{|c|}{ Chromosomes } \\
\hline & $\begin{array}{c}\text { before cross } \\
\text { over }\end{array}$ & $r_{c o}$ & & $r_{c p}$ & $\begin{array}{c}\text { after cross } \\
\text { over }\end{array}$ & C.C.No. \\
\hline $1^{\prime}$ & $3-4-1-5-6-2$ & 0.32 & Yes & 4 & $6-2-3-4-1-5$ & 1"’ \\
\hline $2^{\prime}$ & $2-3-5-4-6-1$ & 0.76 & No & & $2-3-5-4-6-1$ & 2, \\
\hline $3^{\prime}$ & $1-3-4-5-2-6$ & 0.08 & Yes & 1 & $3-4-5-2-6-1$ & $3^{\prime,}$ \\
\hline $4^{\prime}$ & $6-1-2-3-4-5$ & 0.019 & Yes & 2 & $2-3-4-5-6-1$ & 4 '” \\
\hline $5^{\prime}$ & $2-3-1-5-6-4$ & 0.89 & No & & $2-3-1-5-6-4$ & 5, \\
\hline $6^{\prime}$ & $6-1-2-3-4-5$ & 0.28 & Yes & 3 & $3-4-5-6-1-2$ & 6 , \\
\hline $7^{\prime}$ & $2-3-5-4-6-1$ & 0.92 & No & & $2-3-5-4-6-1$ & $7^{\prime \prime}$ \\
\hline
\end{tabular}

$\boldsymbol{r}_{c o}$ - random number for cross over; $\boldsymbol{r}_{c p}$ - cutting point; C.C.No. - chromosome number after cross over

Table 11. Chromosomes before and after mutation.

\begin{tabular}{|c|c|c|c|c|c|c|c|c|c|}
\hline $\begin{array}{l}\text { C.C. } \\
\text { No. }\end{array}$ & $\begin{array}{c}\text { Chromosomes } \\
\text { before } \\
\text { mutation }\end{array}$ & & & $r_{m}$ & & & & $\begin{array}{l}\text { Chromosomes } \\
\text { after mutation }\end{array}$ & $\begin{array}{l}\text { M.C. } \\
\text { No. }\end{array}$ \\
\hline 1 '” & $6-2-3-4-1-5$ & 0.31 & 0.49 & 0.74 & 0.92 & 0.84 & 0.04 & $6-2-3-4-1-5$ & $1, ’$ \\
\hline 2'” & $2-3-5-4-6-1$ & 0.1 & 0.43 & 0.21 & 0.85 & 0.012 & 0.54 & $2-3-5-4-1-6$ & $2^{\prime,}$, \\
\hline $3^{\prime \prime}$ & $3-4-5-2-6-1$ & 0.01 & 0.56 & 0.67 & 0.89 & 0.005 & 0.45 & $4-3-5-2-1-6$ & $3,$, \\
\hline 4', & $2-3-4-5-6-1$ & 0.008 & 0.003 & 0.61 & 0.07 & 0.09 & 0.12 & $3-4-2-5-6-1$ & $4, \%$ \\
\hline 5, & $2-3-1-5-6-4$ & 0.4 & 0.21 & 0.006 & 0.32 & 0.007 & 0.38 & $2-3-5-1-4-6$ & $5,$, \\
\hline $6^{\prime \prime}$ & $3-4-5-6-1-2$ & 0.05 & 0.003 & 0.002 & 0.07 & 0.94 & 0.12 & $3-4-6-5-1-2$ & $6,$, \\
\hline $7^{\prime \prime}$ & $2-3-5-4-6-1$ & 0.1 & 0.43 & 0.21 & 0.85 & 0.012 & 0.54 & $2-3-5-4-1-6$ & $7^{\prime \prime \prime}$ \\
\hline
\end{tabular}

Table 12. Chromosomes after first iteration / New population chromosomes.

\begin{tabular}{|c|c|c|c|c|c|c|}
\hline $\begin{array}{l}\text { M.C. } \\
\text { No. }\end{array}$ & $\begin{array}{l}\text { Chromosomes } \\
\text { after mutation }\end{array}$ & C.No. & $\begin{array}{l}\text { Machine } \\
\text { sequence }\end{array}$ & $\begin{array}{c}\text { Total } \\
\text { Machine } \\
\text { Cost } \\
(\mathrm{Z} 1) \\
\end{array}$ & $\begin{array}{c}\text { Total } \\
\text { number of } \\
\text { machines } \\
(\mathrm{Z} 2)\end{array}$ & $\begin{array}{c}\text { Total } \\
\text { flow } \\
\text { distance } \\
\text { (Z3) }\end{array}$ \\
\hline 1 ', & $6-2-3-4-1-5$ & 1 & $\begin{array}{c}4-3-5-7-1-8-4- \\
6-2-9-8-3-1-7\end{array}$ & 261589 & 14 & 1160 \\
\hline $2^{\prime,}$, & $2-3-5-4-1-6$ & 2 & $\begin{array}{c}4-3-5-6-9-8-3- \\
7-1-8-2-7-9\end{array}$ & 222566 & 13 & 1363 \\
\hline $3,$, & $4-3-5-2-1-6$ & 3 & $\begin{array}{l}4-7-3-5-1-8-6- \\
9-8-3-1-7-2-9\end{array}$ & 246687 & 14 & 1300 \\
\hline 4 ,', & $3-4-2-5-6-1$ & 4 & $\begin{array}{l}4-7-1-3-5-6-9- \\
8-3-1-8-2-7-9\end{array}$ & 246687 & 14 & 1413 \\
\hline $5,$, & $2-3-5-1-4-6$ & 5 & $\begin{array}{c}4-3-4-5-6-9-8- \\
3-7-1-8-2-7-9\end{array}$ & 249725 & 14 & 1376 \\
\hline 6 ,", & $3-4-6-5-1-2$ & 6 & $\begin{array}{c}7-1-4-3-5-6-9- \\
8-3-1-8-2-9-7\end{array}$ & 246687 & 14 & 1367 \\
\hline $7, \cdot$, & $2-3-5-4-1-6$ & 7 & $\begin{array}{c}4-3-5-6-9-8-3- \\
7-1-8-2-7-9\end{array}$ & 222566 & 13 & 1363 \\
\hline
\end{tabular}


Table 13. Computation results.

\begin{tabular}{|c|c|c|c|c|c|c|c|c|}
\hline $\begin{array}{c}\text { Problem } \\
\text { no. }\end{array}$ & $\begin{array}{c}\text { No. of } \\
\text { machine } \\
\text { types }\end{array}$ & $\begin{array}{l}\text { No. of } \\
\text { products }\end{array}$ & Method & $\begin{array}{c}\text { Total } \\
\text { flow } \\
\text { distance } \\
\text { in units }\end{array}$ & $\begin{array}{l}\text { Total } \\
\text { machine } \\
\text { cost in } \\
\text { Rs. }\end{array}$ & $\begin{array}{l}\text { Total no. } \\
\text { of } \\
\text { machines } \\
\text { in the } \\
\text { sequence }\end{array}$ & $\begin{array}{l}\text { Product's } \\
\text { sequence }\end{array}$ & $\begin{array}{l}\text { Optimal } \\
\text { final } \\
\text { linear } \\
\text { sequence }\end{array}$ \\
\hline \multirow{3}{*}{1} & \multirow{3}{*}{14} & \multirow{3}{*}{4} & Proposed & 475 & 73,567 & 14 & $1-3-2-4$ & $\begin{array}{c}1-14-2- \\
3-4-6-8- \\
9-7-13- \\
5-10-11- \\
12\end{array}$ \\
\hline & & & $\begin{array}{c}\text { Siva Kumar } \\
\mathrm{M} \text { et al }\end{array}$ & 475 & 73,567 & 14 & $1-3-2-4$ & $\begin{array}{c}1-14-2- \\
3-4-6-8- \\
9-7-13- \\
5-10-11- \\
12 \\
\end{array}$ \\
\hline & & & $\begin{array}{l}\text { Pillai et al + } \\
\text { Chen et al }\end{array}$ & 475 & 73,567 & 14 & $1-3-2-4$ & $\begin{array}{c}14-1-2- \\
3-4-6-8- \\
9-7-13- \\
5-10-11- \\
12 \\
\end{array}$ \\
\hline \multirow{3}{*}{2} & \multirow{3}{*}{10} & \multirow{3}{*}{5} & Proposed & 12800 & $11,51,057$ & 10 & $1-2-3-4-5$ & $\begin{array}{c}5-3-2-7- \\
1-8-9-6- \\
4-10\end{array}$ \\
\hline & & & $\begin{array}{c}\text { Siva Kumar } \\
\mathrm{M} \text { et al }\end{array}$ & 12800 & $11,51,057$ & 10 & $1-2-3-4-5$ & $\begin{array}{c}5-3-2-7- \\
1-8-9-6- \\
4-10 \\
\end{array}$ \\
\hline & & & Pillai et al & 12800 & $11,51,057$ & 10 & $1-5-3-4-2$ & $\begin{array}{c}5-3-2-7- \\
1-8-9-6- \\
4-10\end{array}$ \\
\hline \multirow{3}{*}{3} & \multirow{3}{*}{7} & \multirow{3}{*}{5} & Proposed & 8800 & $1,01,000$ & 8 & $1-4-3-2-5$ & $\begin{array}{c}4-1-3-2- \\
6-5-1-7\end{array}$ \\
\hline & & & $\begin{array}{c}\text { Siva Kumar } \\
\text { M et al }\end{array}$ & 9000 & $1,14,000$ & 9 & $1-2-3-4-5$ & $\begin{array}{c}\text { 4-6-1-7- } \\
1-3-2-6- \\
5\end{array}$ \\
\hline & & & Pillai et al & 9000 & $1,14,000$ & 9 & $1-2-3-4-5$ & $\begin{array}{c}\text { 4-6-1-7- } \\
1-3-2-6- \\
5\end{array}$ \\
\hline \multirow{3}{*}{4} & \multirow{3}{*}{15} & \multirow{3}{*}{4} & Proposed & 890 & 58,562 & 12 & $3-4-1-2$ & $\begin{array}{c}2-10-12- \\
14-13-7- \\
11-15-5- \\
3-1-4\end{array}$ \\
\hline & & & $\begin{array}{l}\text { Siva Kumar } \\
\text { M et al }\end{array}$ & 890 & 58,562 & 12 & $3-4-1-2$ & $\begin{array}{c}2-10-12- \\
14-13-7- \\
11-15-5- \\
3-1-4\end{array}$ \\
\hline & & & Chen et al & 989 & 58,562 & 12 & $3-4-1-2$ & $\begin{array}{c}2-10-12- \\
14-13-7- \\
11-15-5- \\
1-4-3\end{array}$ \\
\hline
\end{tabular}




\begin{tabular}{|c|c|c|c|c|c|c|c|c|}
\hline \multirow{3}{*}{5} & \multirow{3}{*}{14} & \multirow{3}{*}{6} & Proposed & 2388 & $2,96,406$ & 14 & \multirow{3}{*}{$\begin{array}{c}5-3-4-1- \\
6-2\end{array}$} & $\begin{array}{l}2-4-8-5- \\
3-11-13- \\
14-7-12- \\
9-1-10-6\end{array}$ \\
\hline & & & $\begin{array}{c}\text { Siva Kumar } \\
\mathrm{M} \text { et al }\end{array}$ & 2388 & $2,96,406$ & 14 & & $\begin{array}{l}2-4-8-5- \\
3-11-13- \\
14-7-12- \\
9-1-10-6\end{array}$ \\
\hline & & & Chen et al & 2939 & $2,96,406$ & 14 & & $\begin{array}{l}\text { 4-2-8-5- } \\
3-11-13- \\
14-1-10- \\
7-12-9-6\end{array}$ \\
\hline \multirow{3}{*}{6} & \multirow{3}{*}{13} & \multirow{3}{*}{5} & Proposed & 640 & $2,69,198$ & 17 & $1-5-2-3-4$ & $\begin{array}{c}12-3-7- \\
1-11-4- \\
8-6-5-8- \\
2-10-9- \\
6-5-7-2\end{array}$ \\
\hline & & & $\begin{array}{c}\text { Siva Kumar } \\
\text { M et al }\end{array}$ & 776 & $3,14,687$ & 19 & $5-4-1-3-2$ & $\begin{array}{c}4-8-6-1- \\
11-4-5- \\
8-2-12- \\
3-7-1- \\
10-9-5- \\
7-2-6\end{array}$ \\
\hline & & & Chen et al & 694 & $2,69,198$ & 17 & $5-4-1-3-2$ & $\begin{array}{c}12-3-7- \\
1-11-4- \\
8-6-5-8- \\
2-10-9- \\
5-7-2-6\end{array}$ \\
\hline \multirow{3}{*}{7} & \multirow{3}{*}{9} & \multirow{3}{*}{6} & Proposed & 1080 & $2,34,430$ & 13 & $\begin{array}{c}6-1-4-5- \\
2-3\end{array}$ & $\begin{array}{c}\text { 7-3-5-1- } \\
8-4-6-2- \\
9-8-1-7- \\
3\end{array}$ \\
\hline & & & $\begin{array}{c}\text { Siva Kumar } \\
\mathrm{M} \text { et al }\end{array}$ & \multicolumn{5}{|c|}{ Infeasible solution } \\
\hline & & & Chen et al & 1174 & $2,34,430$ & 13 & $\begin{array}{c}4-5-3-6- \\
2-1\end{array}$ & $\begin{array}{c}\text { 3-5-7-1- } \\
8-4-6-2- \\
9-8-1-7- \\
3\end{array}$ \\
\hline \multirow{3}{*}{8} & \multirow{3}{*}{7} & \multirow{3}{*}{7} & Proposed & 558 & $1,86,514$ & 13 & $\begin{array}{c}2-3-5-1- \\
4-6-7\end{array}$ & $\begin{array}{c}4-2-1-3- \\
5-7-1-2- \\
4-6-7-5- \\
6\end{array}$ \\
\hline & & & $\begin{array}{c}\text { Siva Kumar } \\
\text { M et al }\end{array}$ & \multicolumn{5}{|c|}{ Infeasible solution } \\
\hline & & & Chen et al & 606 & $2,06,368$ & 14 & $\begin{array}{c}5-2-4-3- \\
7-6-1\end{array}$ & $\begin{array}{c}4-2-1-3- \\
5-4-6-7- \\
1-3-7-2- \\
5-6\end{array}$ \\
\hline
\end{tabular}




\section{Appendix}

Table A1. Operation sequences and product demand of example problems.

\begin{tabular}{|c|c|c|c|}
\hline Problem no & Products & Operation sequence & Product demand \\
\hline 1 & 1 & $2-3-4-6-8-9-7$ & 20 \\
\hline Pillai et al & 2 & $14-2-3-4-5-10-11-12$ & 10 \\
\hline+ & 3 & 2-4-6-8-9-13 & 15 \\
\hline Chen et al & 4 & $1-2-3-5-11-12$ & 10 \\
\hline \multirow{5}{*}{$\begin{array}{c}2 \\
\text { Pillai et al }\end{array}$} & 1 & $1-8-9-6-4$ & 700 \\
\hline & 2 & $5-3-2-7$ & 600 \\
\hline & 3 & $5-3-2-9$ & 500 \\
\hline & 4 & $3-7-6-4$ & 400 \\
\hline & 5 & $3-2-7-9-10$ & 300 \\
\hline \multirow{5}{*}{$\begin{array}{c}3 \\
\text { Pillai et al }\end{array}$} & 1 & $1-3-2-6-5$ & 800 \\
\hline & 2 & $4-6-1-7$ & 400 \\
\hline & 3 & $4-1-6-5$ & 300 \\
\hline & 4 & $4-3-2-5$ & 200 \\
\hline & 5 & $4-1-3-2$ & 100 \\
\hline \multirow{4}{*}{$\begin{array}{c}4 \\
\text { Chen et al }\end{array}$} & 1 & $14-13-7-15$ & 34 \\
\hline & 2 & $2-10-12-13$ & 29 \\
\hline & 3 & $11-15-5-3$ & 94 \\
\hline & 4 & $15-5-1-4$ & 89 \\
\hline \multirow{6}{*}{$\begin{array}{c}5 \\
\text { Chen et al }\end{array}$} & 1 & $4-5-3-9$ & 69 \\
\hline & 2 & $5-3-7-6$ & 13 \\
\hline & 3 & $13-7-12-9$ & 113 \\
\hline & 4 & $8-5-3-14$ & 72 \\
\hline & 5 & $11-13-14-7$ & 131 \\
\hline & 6 & $2-5-1-10$ & 36 \\
\hline \multirow{5}{*}{6} & 1 & 8-2-10-9-6 & 34 \\
\hline & 2 & $4-8-6-5$ & 2 \\
\hline & 3 & $1-11-4-5$ & 30 \\
\hline & 4 & $12-3-7-1$ & 36 \\
\hline & 5 & $10-9-5-7-2$ & 48 \\
\hline \multirow{6}{*}{7} & 1 & $4-6-8-1$ & 8 \\
\hline & 2 & $7-1-8-2$ & 15 \\
\hline & 3 & $5-6-9-8-3$ & 32 \\
\hline & 4 & $3-5-1-8$ & 50 \\
\hline & 5 & 5-9-8-1-7 & 42 \\
\hline & 6 & $4-6-2-9$ & 29 \\
\hline \multirow{7}{*}{8} & 1 & $1-3-5-7$ & 12 \\
\hline & 2 & $2-4-6-7$ & 18 \\
\hline & 3 & $3-5-7-1$ & 15 \\
\hline & 4 & $4-2-3-7$ & 16 \\
\hline & 5 & $7-2-5-6$ & 20 \\
\hline & 6 & $1-3-2-6$ & 13 \\
\hline & 7 & $5-4-7-6$ & 14 \\
\hline
\end{tabular}


Table A2. Machine types and its duplicates for the example problems.

\begin{tabular}{|c|c|c|c|c|c|c|c|c|c|c|c|c|c|c|c|}
\hline \multirow{2}{*}{$\begin{array}{l}\text { Problem } \\
\text { No. }\end{array}$} & \multicolumn{15}{|c|}{ Machines Types } \\
\hline & 1 & 2 & 3 & 4 & 5 & 6 & 7 & 8 & 9 & 10 & 11 & 12 & 13 & 14 & 15 \\
\hline 1 & 1 & 1 & 1 & 1 & 1 & 1 & 1 & 1 & 1 & 1 & 1 & 1 & 1 & 1 & \\
\hline 2 & 1 & 1 & 1 & 1 & 1 & 1 & 1 & 1 & 1 & 1 & & & & & \\
\hline 3 & 2 & 1 & 1 & 1 & 1 & 2 & 1 & & & & & & & & \\
\hline 4 & 1 & 1 & 1 & 2 & 1 & 2 & 2 & 2 & 2 & 2 & 1 & 2 & 1 & 1 & 1 \\
\hline 5 & 1 & 1 & 1 & 1 & 1 & 1 & 1 & 1 & 1 & 1 & 1 & 1 & 1 & 1 & \\
\hline 6 & 2 & 2 & 2 & 2 & 2 & 2 & 2 & 2 & 2 & 1 & 2 & 1 & 2 & & \\
\hline 7 & 2 & 1 & 2 & 2 & 1 & 1 & 2 & 2 & 2 & & & & & & \\
\hline 8 & 2 & 2 & 2 & 2 & 2 & 2 & 2 & & & & & & & & \\
\hline
\end{tabular}

Table A3. Machine types and its cost for the example literature problems.

\begin{tabular}{ccccccccc}
\hline Machines & \multicolumn{7}{c}{ Problem No. } \\
\cline { 2 - 8 } Types & 1 & 2 & 3 & \multicolumn{1}{c}{4} & \multicolumn{1}{c}{5} & \multicolumn{1}{c}{6} & \multicolumn{1}{c}{ ( } \\
\hline 1 & 8,788 & 84,565 & 10,000 & 8,788 & 21,011 & 20,831 & 24,121 & 12,315 \\
2 & 6,589 & 74,325 & 15,000 & 6,589 & 28,752 & 12,380 & 4,546 & 14,445 \\
3 & 3,512 & 59,874 & 16,000 & 3,512 & 26,354 & 22,658 & 25,742 & 19,854 \\
4 & 6,541 & 39,998 & 12,000 & 6,541 & 17,655 & 24,658 & 27,159 & 16,547 \\
5 & 3,254 & 47,775 & 11,000 & 3,254 & 21,357 & 17,230 & 26,738 & 15,487 \\
6 & 9,874 & 22,225 & 13,000 & 9,874 & 16,554 & 16,660 & 18,822 & 13,221 \\
7 & 6,547 & 14,411 & 14,000 & 6,547 & 11,357 & 12,557 & 21,612 & 11,315 \\
8 & 8,541 & 15,455 & & 8,541 & 30,699 & 6,088 & 979 & \\
9 & 3,256 & $1,34,545$ & & 3,256 & 19,220 & 10,912 & 12,257 & \\
10 & 1,111 & $6,57,884$ & & 1,111 & 12,632 & 27,943 & & \\
11 & 2,222 & & & 2,222 & 10,228 & 24,234 & & \\
12 & 3,333 & & & 3,333 & 24,998 & 8,132 & & \\
13 & 4,445 & & & 4,445 & 27,111 & 20,831 & & \\
14 & 5,554 & & & 5,554 & 28,478 & & & \\
15 & & & & 6,666 & & & & \\
\hline
\end{tabular}


Read the number of machine types $(\mathrm{nm})$, number of duplicate machines in each type $(m t n[])$, number of products $(n p)$, number of machine types in each product ( $\mathrm{nmp}[])$, machine type sequence for each product (pseq[][]), distance of each product $(p d[])$, machine cost $(m c[])$ and the product sequence ( $p n o[])$

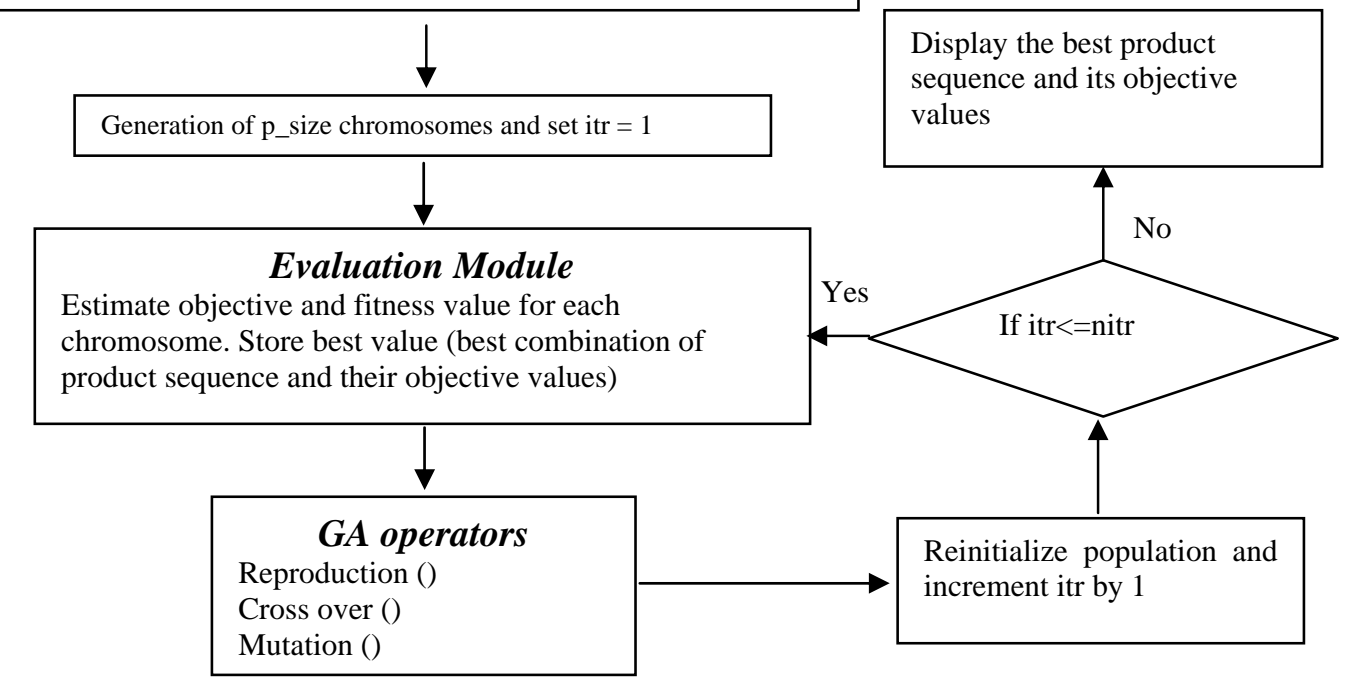

Fig. 1. General schematic diagram of genetic algorithm. 


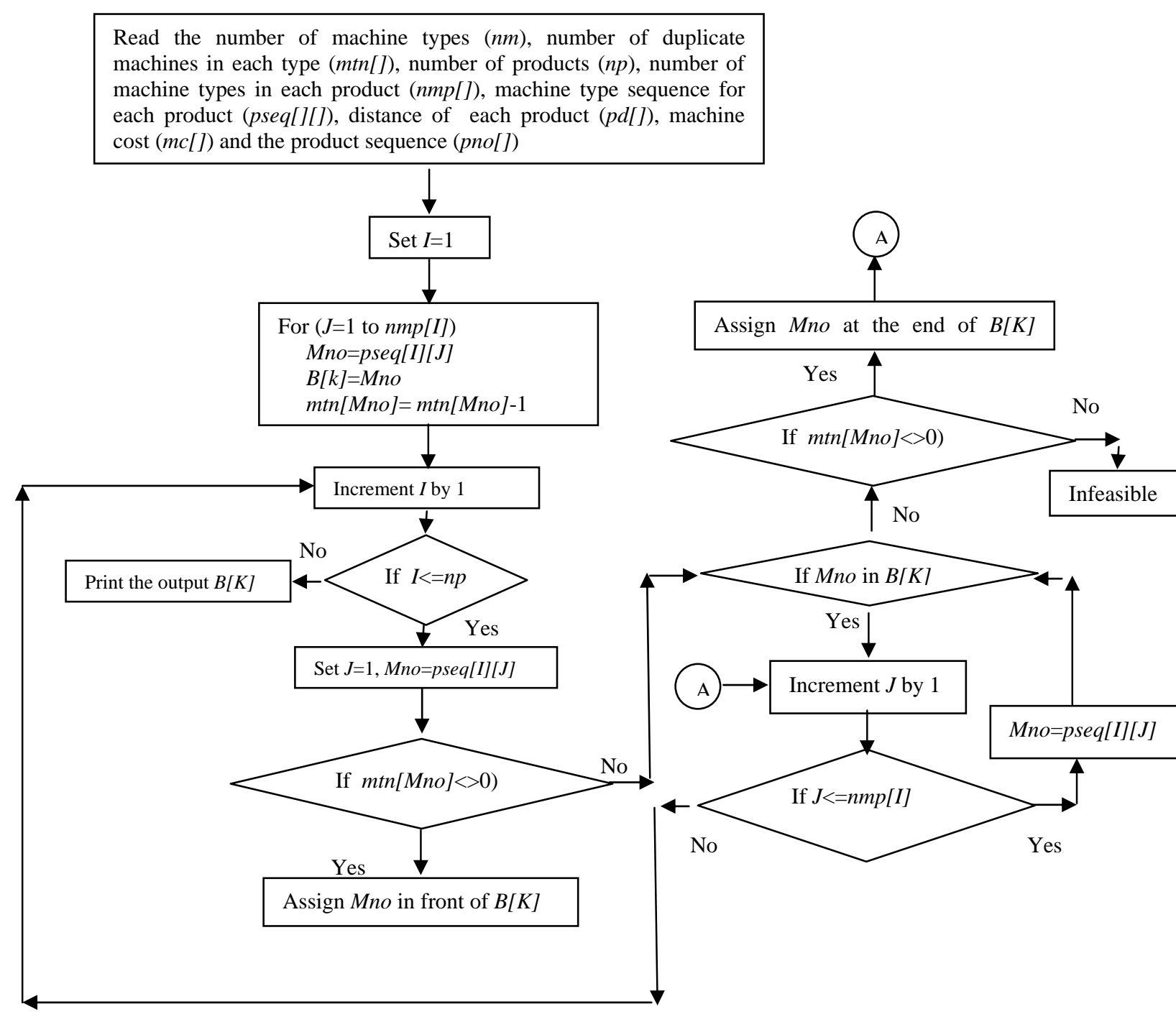

Fig. 2. Evaluation of chromosome. 


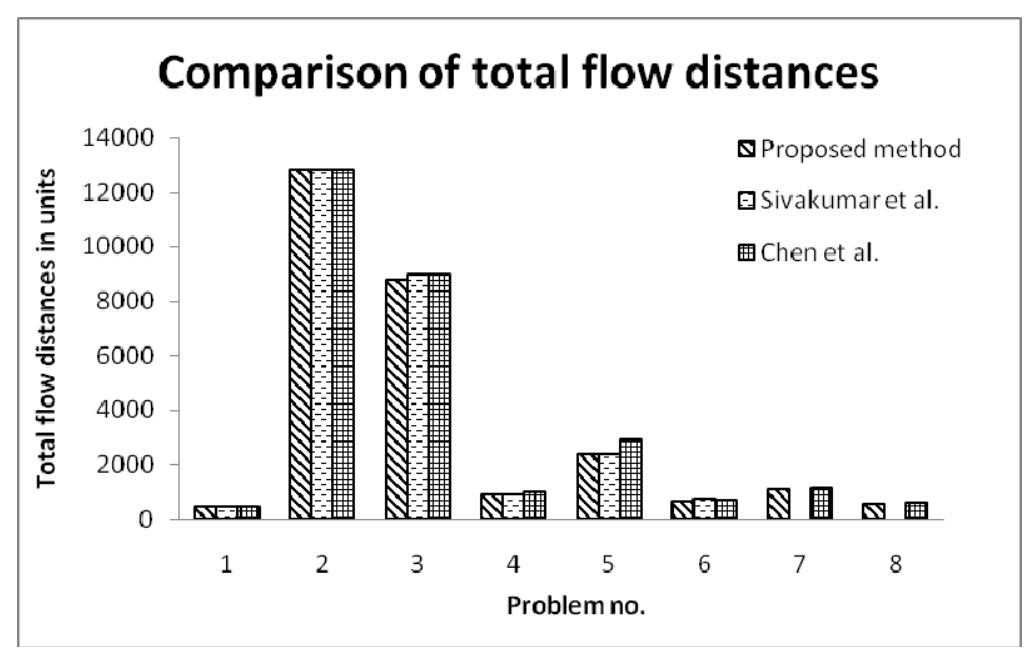

Fig. 3 Comparison of total flow distances

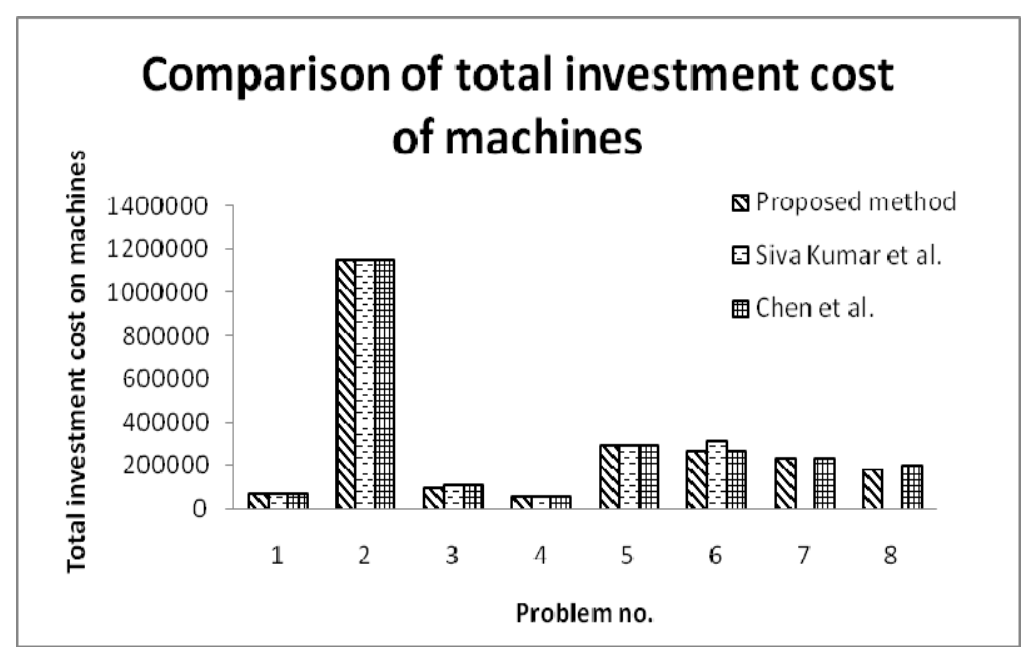

Fig. 4 Comparison of total investment cost of machines

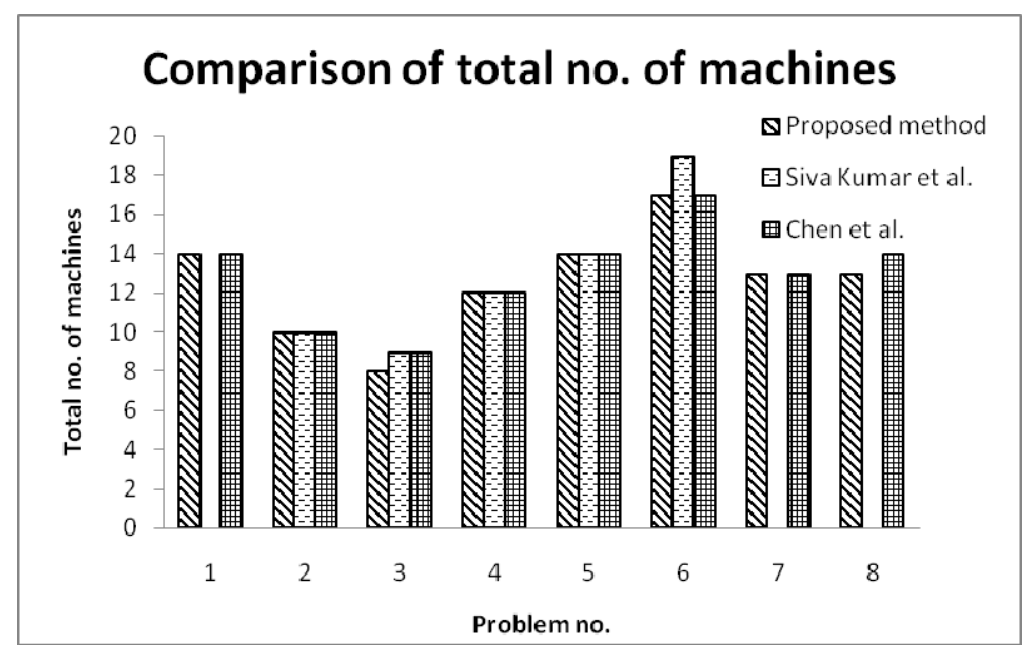

Fig. 5 Comparison of total number of machines 


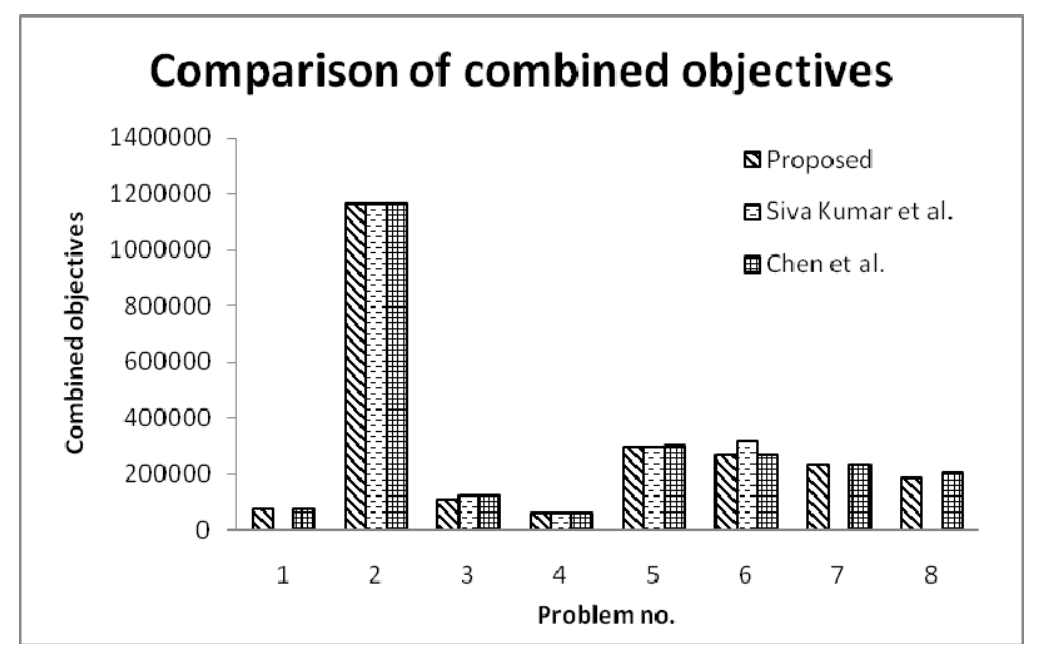

Fig. 6 Comparison of combined objectives

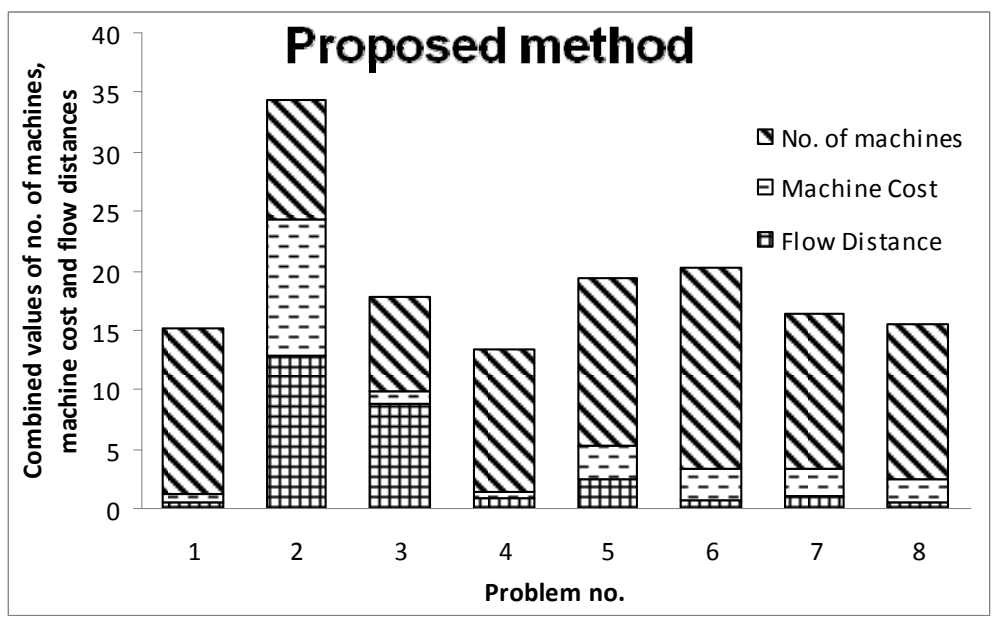

${ }^{\#}$ Fig. 7 Problem number versus combined values of number of machines, machine cost, and flow distances for the proposed method

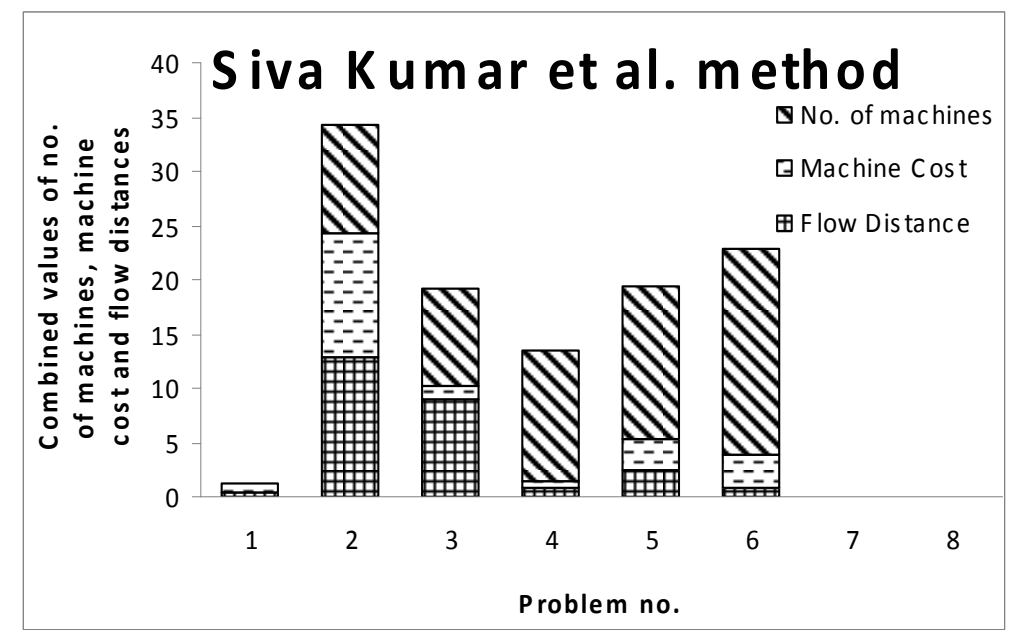

${ }^{\#}$ Fig. 8 Problem number versus combined values of number of machines, machine cost, and flow distances for the method of Siva Kumar M et al. 


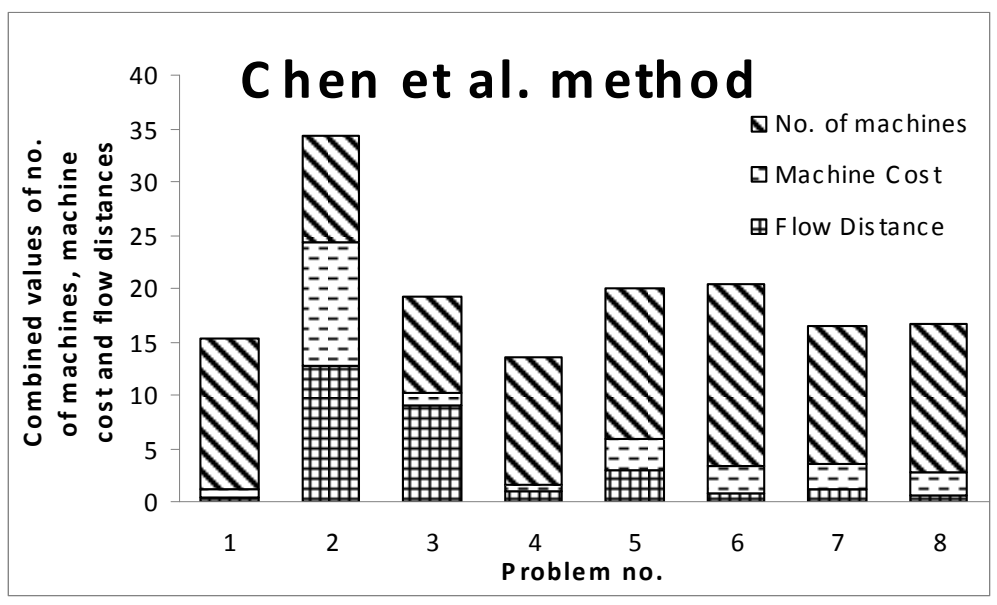

\#Fig. 9 Problem number versus combined values of number of machines, machine cost, and flow distances for the method of Chen et al. 